\title{
Patient Selection for Deep Brain Stimulation for Parkinson's Disease----A Very Convenient Tool
}

\author{
Amit Kumar Ghosh* \\ Consultant Neurosurgeon, Institute of Neurosciences Kolkata, India
}

Submission: January 09, 2019; Published: April 24, 2019

*Corresponding author: Amit Kumar Ghosh, Consultant Neurosurgeon, Institute of Neurosciences Kolkata, India

\begin{abstract}
Deep brain stimulation (DBS) for Parkinson Disease (PD) is performed on patients with medically intractable PD. Selection of patients requires a multidisciplinary team that includes a neurosurgeon trained in functional neurosurgery, a movement disorders neurologist, a neuropsychologist, psychiatrist and neurophysiologist. This is a very convenient criteria to identify DBS patient for PD.

Keywords: Progressive supranuclear palsy, Multiple system atrophy, Cortico basal degeneration, Lewy body dementia, Unified Parkinson's disease rating scale, Parkinson's disease, Neurologists, patients, DBS surgery

Abbreviations: PSP: Progressive Supranuclear Palsy, MSA: Multiple System Atrophy; CBD: Cortico Basal Degeneration; LBD: Lewy Body Dementia; UPDRS: Unified Parkinson's Disease Rating Scale
\end{abstract}

\section{Introduction}

Deep brain stimulation has been shown to consistently benefit patients of medically intractable idiopathic Parkinson's disease [1-8]. This is a very convenient list of 10-points criteria to identify patients who are the candidate for DBS surgery in Parkinson's disease [1-8] (Table 1).

Table 1: DBS 10-points selection criteria for Parkinson's disease patients.

\begin{tabular}{|c|c|c|c|}
\hline 1. & Age<75 years & Yes & No \\
\hline 2. & Idiopathic PD (No PSP/MSA/ CBD/LBD etc) & Yes & No \\
\hline 3. & Levodopa responsive & Yes & No \\
\hline \multirow{2}{*}{4.} & Poor/adverse response to drug & yes & No \\
\cline { 2 - 4 } & a) Increased off period & Yes & No \\
\cline { 2 - 4 } & b) Disabling dyskinesia & Yes & No \\
\hline \multirow{2}{*}{5.} & Degree of disability (UPDRS part III score) $>25$ & Yes & No \\
\hline 6. & Neuropsychology, MMSE $>24$ & yes & No \\
\hline \multirow{2}{*}{7.} & $\begin{array}{c}\text { Levodopa Challenge } \\
\text { Response Positive }\end{array}$ & \\
& (30\% improvement in UPDRS after 12-hours off & yes & No \\
\hline 8. & Advanced co-morbidity & Yes & No \\
\hline 9. & long term anticoagulation & Yes & No \\
\hline 10. & Willing for surgery and programming & Yes & No \\
\hline
\end{tabular}

\section{Discussion}

The above list is very convenient for students and general neurologists to identify patients for DBS surgery for Parkinson's disease. If patients fulfil these criteria, then they can be selected for DBS.

\section{References}

1. Groiss SJ, Wojtecki L, Sudmeyer M, Schnitzler A (2009) Deep Brain Stimulation in Parkinson's Disease: Ther Adv Neurol Disord 2(6): 2028.

2. Mehanna R, Hubert HF, Aparna Wagle Shukla, Jawad A Bajwa (2013) Deep brain stimulation in Parkinson's disease. Translational Neurodegeneration 2:22

3. N K Patel, P Plaha, K O Sullivan, Mc Carter R, Heywood P, et al. (2003) MRI directed bilateral stimulation of the subthalamic nucleus in patients with Parkinson's disease. J Neurol Neurosurg Psychiatry 2003 74(12): 1631-1637.

4. Hamid NA, Mitchell RD, Mocroft P, Westby GW, Milner J, et al. (2003) Targeting the subthalamic nucleus for deep brain stimulation: technical approach and fusion of pre- and postoperative MR images to define accuracy of lead placement. J Neurol Neurosurg Psychiatry 76(3): 409-414

5. Deogaonkar M, Vitek JL (2008) Globus Pallidus Stimulation for Parkinson's Disease. Textbook of Stereotactic and Functional Neurosurgery 1577-1602.

6. Machado A, Rezai AR, Kopell BH, Gross RE, Sharan AD (2006) Deep Brain Stimulation for Parkinson's Disease: Surgical Technique and Perioperative Management. Movement Disorders 21(14): S247-S258. 
7. Albert J Fenoy, Richard K, Simpson (2014) Risks of common complications in deep brain stimulation surgery: management and avoidance. J Neurosurg 120(1): 132-139.
8. Machado AG, Deogaonkar M, Cooper S (2012) Deep brain stimulation for movement disorders: Patient selection and technical options. Cleve Clin J Med 79(suppl 2): S19-S24.

\section{Your next submission with Juniper Publishers will reach you the below assets}

- Quality Editorial service

- Swift Peer Review

- Reprints availability

- E-prints Service

- Manuscript Podcast for convenient understanding

- Global attainment for your research

- Manuscript accessibility in different formats

( Pdf, E-pub, Full Text, Audio)

- Unceasing customer service

Track the below URL for one-step submission https://juniperpublishers.com/online-submission.php 